\title{
Strategi Pengembangan Usaha dan Pemasaran Benih Ikan Patin Siam (Pangasianodon hypopthalmus) Dengan Sistem Jejaring pada Cabang Dinas Kelautan dan Perikanan Wilayah Utara Provinsi Jawa Barat
}

\author{
Business Development Strategy and Marketing of Siamese Patin Seed (Pangasionodon \\ hypophthalmus) with a Networking System in the North Branch of Marine and Fisheries \\ Service of West Java Province
}

\author{
Titus Pramono ${ }^{1^{*}}$, Suryahadi ${ }^{2 \sharp}$, dan Wini Trilaksani ${ }^{3 \#}$ \\ ${ }^{1}$ Program Studi Pengembangan Industri Kecil dan Menengah, Sekolah Pascasarjana IPB \\ ${ }^{2}$ Departemen Ilmu Nutrisi dan Teknologi Pakan, Fakultas Peternakan, IPB \\ ${ }^{3}$ Departemen Teknologi Hasil Perairan Fakultas Perikanan dan Ilmu Kelautan, IPB \\ \#Jl. Agatis Kampus IPB Dramaga Bogor 16128
}

\begin{abstract}
ABSTRAK
Produksi benih ikan Patin (Pangasianodon hypopthalmus) di Subang Jawa Barat belum mampu disediakan sesuai kebutuhan pasar. Produksi benih ikan patin perlu ditingkatkan melalui Cabang Dinas Kelautan dan Perikanan Wilayah Jawa Barat (CDKPWU) dengan pola kemitraan inti dan plasma. Tujuan penelitian adalah mengidentifikasi faktor internal dan eksternal yang memengaruhi pemasaran benih ikan patin dengan sistem jejaring antara CDKPWU dengan mitra, mengidentifikasi keunggulan serta kelemahan pada proses jejaring yang terjadi antara pihak CDKPWU dan mitra yang tergabung dan menyusun strategi pengembangan usaha dan pemasaran benih ikan patin paling efektif. Metode yang digunakan dalam penelitian ini meliputi (1) Analisis Valuable, Rare, Imitate to Cost dan Organized (VRIO), (2) Analisis Political-Legal, Economic, Social, Technology (PEST), (3) Matriks Internal Factor Evaluation (IFE), (4) Matriks External Factor Evaluation (EFE), dan (5) Matriks Internal External (IE), (6) Analisis Strengths, Weaknesses, Opportunities dan Threats (SWOT) dan (7) Analisis Quantitative Strategic Planning Matrix (QSPM). Skor total pada matriks IFE dan EFE menggambarkan posisi perusahaan stabil dalam merespons situasi eksternal. Total skor matriks IFE 3,3799, menunjukkan kekuatan yang dimiliki CDKPWU dapat mengatasi kelemahan dengan sangat baik. Total skor matriks EFE 2,5943, menunjukkan CDKPWU cukup baik dalam merespon peluang dan meminimalisasi ancaman. Hasil analisis SWOT diperoleh sembilan rumusan alternatif strategi dimana ketiga prioritas rumusan alternatif tersebut yaitu (1) Memperluas jaringan kemitraan produksi untuk peningkatan produksi dan pendapatan masyarakat, (2) Mempertahankan mutu benih dan teknologi proses produksi yang baik, (3) Memanfaatkan kemitraan untuk menjalin hubungan baik dan melakukan audiensi dengan instansi terkait. Berdasarkan analisis QSPM, diperoleh strategi prioritas untuk diterapkan, yaitu memperluas jaringan kemitraan produksi untuk peningkatan produksi dan peningkatan pendapatan masyarakat.
\end{abstract}

Kata kunci: benih, ikan patin, pengembangan usaha, produk perikanan

\begin{abstract}
The production of Siam-catfish (Pangasianodon hypopthalmus) seeds in Subang, West Java can not meet the market demand yet. The production of Siam-catfish seeds need to be improved especially by the main supplier namely the North Branch of Marine and fisheries service of West Java province (CDKPWU) with a partnership pattern between core and plasma. The purposes of this study were to identify internal and external factors that influence the marketing of Siam-catfish seeds with a network system between CDKPWU and partners, to identify advantages and disadvantages
\end{abstract}

\footnotetext{
*) Korespondensi:

Jl. Vistula 5 Perum Green Erfina Residence, Cikampek Selatan, Karawang, Jawa Barat; email: tipram.05@gmail.com
} 
in the network process that occurs between CDKPWU and the partners, and trying to develop the most effective business and marketing srategy of Siam-catfish seeds in order to reach maximum output and outcome. The methods used in this study were as follows: (1) Valuable, Rare, Imitate to Cost and Organized Analysis (VRIO), (2) Political-Legal, Economic, Social, Technology Analysis (PEST), (3) Internal Factor Evaluation Matrix (IFE), (4) External Factor Evaluation Matrix (EFE), (5) Internal External (IE) Matrix, (6) Analysis of Strengths, Weaknesses, Opportunities, and Threats (SWOT) and (7) Quantitative Strategic Planning Matrix (QSPM) Analysis. The result of IFE and EFE matrix indicated that the company's position was stable in response to external situation. The total score of IFE matrix was 3.38, indicating that the strength of CDKPWU can overcome weaknesses very well. The total score of EFE matrix was 2.59, describing that CDKPWU was good enough in responding to opportunities and minimizing threats. The results of the SWOT analysis show nine alternative strategy formulations in which three alternative formulation priorities were (1) Expanding the production partnership network to increase production and increase community income, (2) Maintaining good seed quality and production process technology, (3) Utilizing partnerships to establish good relationship and communication with relevant agencies. Based on the QSPM matrix analysis, the priority strategies are obtained to be implemented, namely expanding the production partnership network to increase production and increase community income

Key words: business development, fishery products, seeds, Siam-catfish

\section{PENDAHULUAN}

Permintaan pasar domestik konsumsi ikan patin per kapita cenderung meningkat tiap tahunnya yakni mencapai 21,9\% terhitung dari tahun 2014 hingga 2017 dengan preferensi produk yang dikonsumsi ikan segar sebanyak 76\%, ikan asing diawetkan 15\% (KKP, 2018). Produksi patin nasional sangat dipengaruhi oleh ketersedian benih ikan patin yang cukup bagi pembudidaya ikan yang salah satunya kelompok pembudidaya Sengonjaya bersama mitra binaan Cabang Dinas Kelautan dan Perikanan Wilayah Utara (CDKPWU) Provinsi Jawa Barat. Jenis-jenis ikan yang dibudidayakan di CDKPWU antara lain ikan patin, lele, dan nila (CDKPWU, 2018). Keberhasilan usaha pembesaran ikan patin sangat ditentukan oleh input bermutu dan proses produksi yang baik. Salah satu input produksi tersebut adalah benih. Mutu benih ikan sangat menentukan output pembesaran ikan patin yang akan dihasilkan. Apabila benih ikan patin mempunyai mutu yang baik maka kemungkinan besar hasil ikan patin konsumsi bermutu baik juga (Yulfiperius et al., 2003). Keberhasilan usaha pembesaran ikan patin untuk meningkatkan produksi ikan patin dibutuhkan ketersedian benih ikan patin yang cukup (Budiardi et al., 2014). Kebutuhan benih ikan patin belum terpenuhi di Subang Provinsi Jawa Barat. Tujuan penelitian ini adalah mengidentifikasi faktor-faktor internal dan eksternal yang mempengaruhi pemasaran benih ikan patin dengan sistem jejaring antara CDKPWU dengan mitra, mengidentifikasi keunggulan serta kelemahan pada proses jejaring yang terjadi antara pihak CDKPWU dan mitra yang tergabung, dan menyusun strategi pengembangan usaha dan pemasaran benih ikan patin yang paling efektif untuk memperoleh hasil maksimal.

\section{METODE PENELITIAN}

Penelitian dilaksanakan di Cijengkol Ds. Rancabango Kec. Patokbeusi-Subang di Cabang Dinas Kelautan dan Perikanan Wilayah Utara Provinsi Jawa Barat (CDKPWU) dan mitra binaan Kelompok Pembudidaya Ikan Patin Sengon Jaya di Dusun Sengonlio Desa Sukamandijaya Kecamatan Ciasem Kabupaten Subang pada bulan April-Mei 2019. Penelitian ini menggunakan kuesioner yang berisi sejumlah pertanyaan tertulis mengenai aspek-aspek yang dikaji untuk memperoleh tanggapan dan informasi dari responden yang dipilih dengan purposive sampling. Dua belas orang responden dimaksud adalah CDKPWU, Anggota Kelompok Pembudidaya Ikan Patin Sengon Jaya di Dusun Sengonlio Desa Sukamandijaya Kecamatan Ciasem Kabupaten Subang dan konsumen.

Kerangka pemikiran penelitian dimuat pada Gambar 1. Penelitian ini menggunakan metode analisis untuk mengidentifikasi dan 
menganalisis lingkungan perusahaan yaitu: (1) Analisis Valuable, Rare, Imitate to Cost dan Organized (VRIO), (2) Analisis Political-Legal, Economic, Social, Technology (PEST), (3) Matriks Internal Factor Evaluation (IFE), (4) Matriks External Factor Evaluation (EFE), (5) Matriks Internal External (IE), (6) Analisis SWOT dan (7) Quantitative Strategic Planning Matrix (QSPM) .

Analisis Valuable, Rare, Imitate to Cost dan Organized (VRIO) digunakan untuk mengetahui kondisi internal perusahaan (Pesic 2012). Analisis VRIO dapat digunakan untuk melihat perbandingan komparatif mengenai kekuatan dan kelemahan kondisi internal perusahaan (Barney dan Hesterly, 2012). Analisis Political-Legal, Economic, Social, Technology (PEST) adalah pendekatan yang paling umum digunakan untuk mempertimbangkan lingkungan bisnis eksternal (Gupta, 2013).

Matriks IFE digunakan untuk untuk menganalisis faktor-faktor internal, mengklasifikasikannya menjadi kekuatan dan kelemahan, kemudian dilakukan pembobotan (David, 2006). Matriks EFE digunakan untuk menganalisis faktor-faktor eksternal, mengklasifi- kasikannya menjadi peluang dan ancaman bagi CDKPWU dan mitra binaan, kemudian dilakukan pembobotan.

Matriks IE adalah alat untuk menentukan posisi suatu perusahaan pada internal dan eksternal perusahaan yang terdiri atas sembilan sel (David, 2006). Analisis SWOT mengidentifikasi berbagai faktor yang secara sistematis untuk merumuskan strategi yang di dasarkan pada logika untuk memaksimalkan kekuatan yang dimiliki dan peluang yang ada. Matriks SWOT merupakan alat untuk menghasilkan kerangka kerja dalam perencanaan strategi (renstra) pencapaian tujuan (Ommani, 2011) yang memengaruhi kecepatan pertumbuhan usaha (Mayer-Haug et al., 2013). Analisis SWOT secara bersamaan mampu meminimalkan kelemahan dan ancaman yang timbul yang berasal dari internal dan eksternal perusahaan (Rangkuti, 2006).

Hubeis dan Najib (2014) menjelaskan Matriks Perencanaan Strategi Kuantitatif (Quantitative Strategic Planning Matrix atau QSPM) secara objektif mengindikasikan alternatif strategi mana yang terbaik.

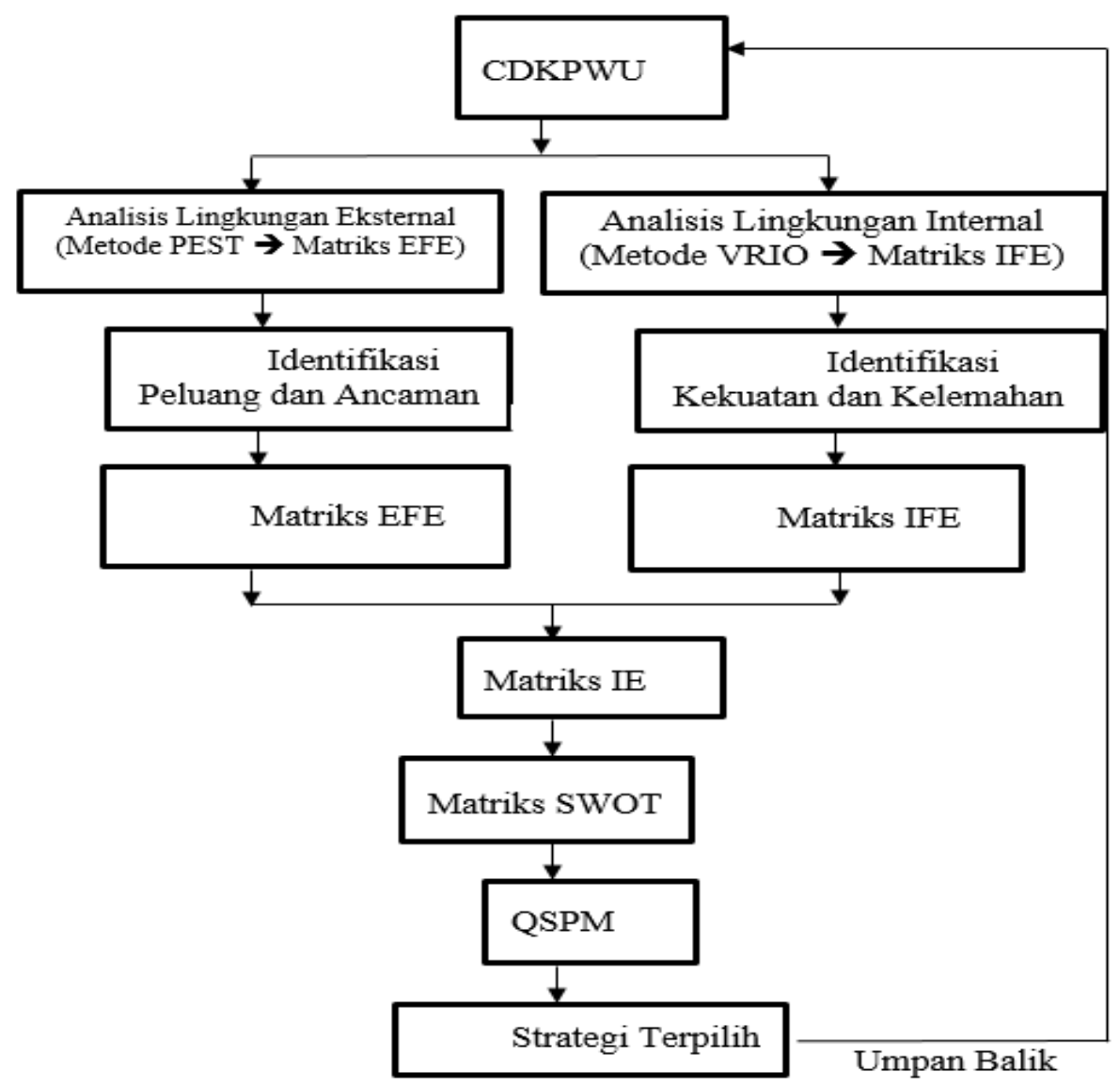

Gambar 1. Kerangka Pemikiran Penelitian 


\section{HASIL DAN PEMBAHASAN}

Secara umum keberhasilan penerapan strategi budidaya ikan patin siam umumnya ditentukan oleh dukungan sumber daya dan kemampuan yang dimiliki oleh perusahaan untuk mengimplementasikannya. Proses analisis strategi pengembangan usaha dan pemasaran benih ikan patin siam dengan sistem jejaring di CDKPWU Cijengkol Subang diawali dengan identifikasi terhadap lingkungan internal yang terdiri dari sumber daya dan kemampuan yang dimiliki oleh CDKPWU dan mitra binaan yang diidentifikasi dan kemudian dianalisis.

\section{Identifikasi dan Analisis Faktor Internal dan Eksternal}

\section{Identifikasi Faktor Internal}

Data penilaian faktor internal berdasarkan analisis VRIO yang dapat dilihat pada Tabel 1, memengaruhi budidaya benih ikan patin sebagai berikut:

a. Bahan baku berupa pakan buatan dan pakan alami (pelet, artemia, cacing sutera) merupakan faktor penting dalam budidaya ikan patin.

Tabel 1. Pengelompokan faktor internal CDKPWU dan mitra binaan berdasarkan VRIO

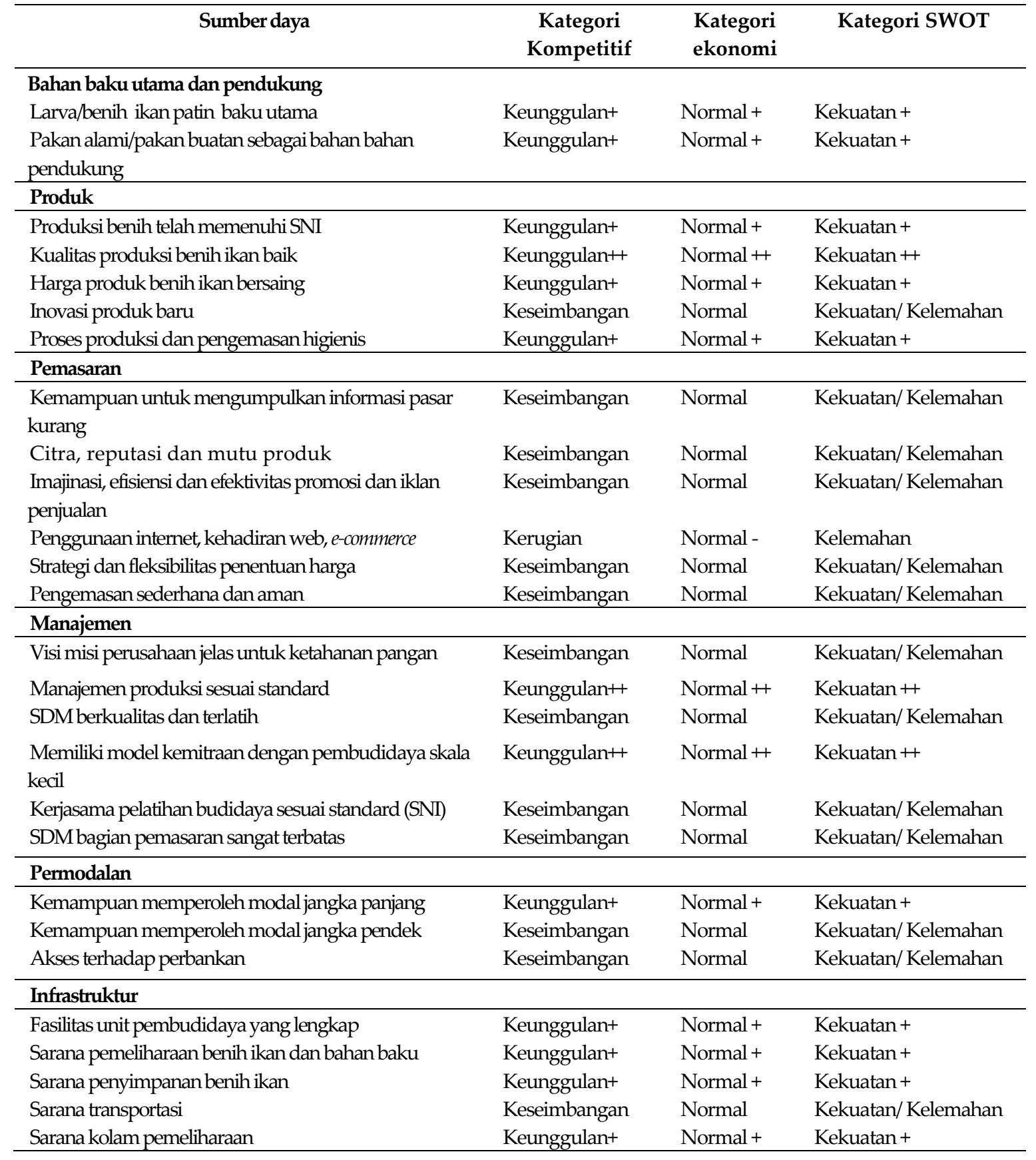


b. Produk hasil budidaya telah memenuhi standard nasional Indonesia.

c. Pemasaran hasil budidaya benih ikan patin siam secara umum masih belum optimal.

d. Permodalan secara umum telah menjadi permasalahan klasik yang dihadapi industri kecil menengah termasuk Kelompok Pembudidaya Ikan Patin Sengon Jaya di Dusun Sengonlio Desa Sukamandijaya Kecamatan Ciasem Kabupaten Subang.

e. Kondisi infrastruktur berupa fasilitas unit budidaya pendederan cukup lengkap

\section{Identifikasi Faktor Eksternal}

Berdasarkan hasil analisis PEST dapat dilihat pada Tabel 2, dari keempat aspek yang ditanyakan kepada narasumber adanya pengendalian impor bahan baku ikan patin mempunyai nilai tertinggi dan dianggap sangat penting. Hal ini menyebabkan bahan baku ikan patin yang sebagian dulunya merupakan produk impor, menjadi berpengaruh terhadap pasar lokal ikan patin. Penilaian pada aspek ekonomi menunjukkan harga bahan baku patin yang cenderung fluktuatif memiliki pengaruh besar terhadap usaha pengelolaan budidaya ikan patin, yang mengakibatkan harga jual benih ikan patin menjadi fluktuatif juga.

Aspek sosial budaya menunjukkan preferensi masyarakat terhadap ikan patin merupakan salah satu hal yang penting. Didukung dengan adanya tingkat konsumsi ikan yang cukup tinggi dan merebaknya trend konsumsi masyarakat terhadap protein hewani non kolesterol. Teknologi pengelolaan budidaya ikan patin higienis yang sesuai SNI dianggap penting oleh narasumber dan merupakan keunggulan produk CDKPWU dan mitra binaan.

Tabel 2. Data faktor eksternal berdasarkan analisis PEST

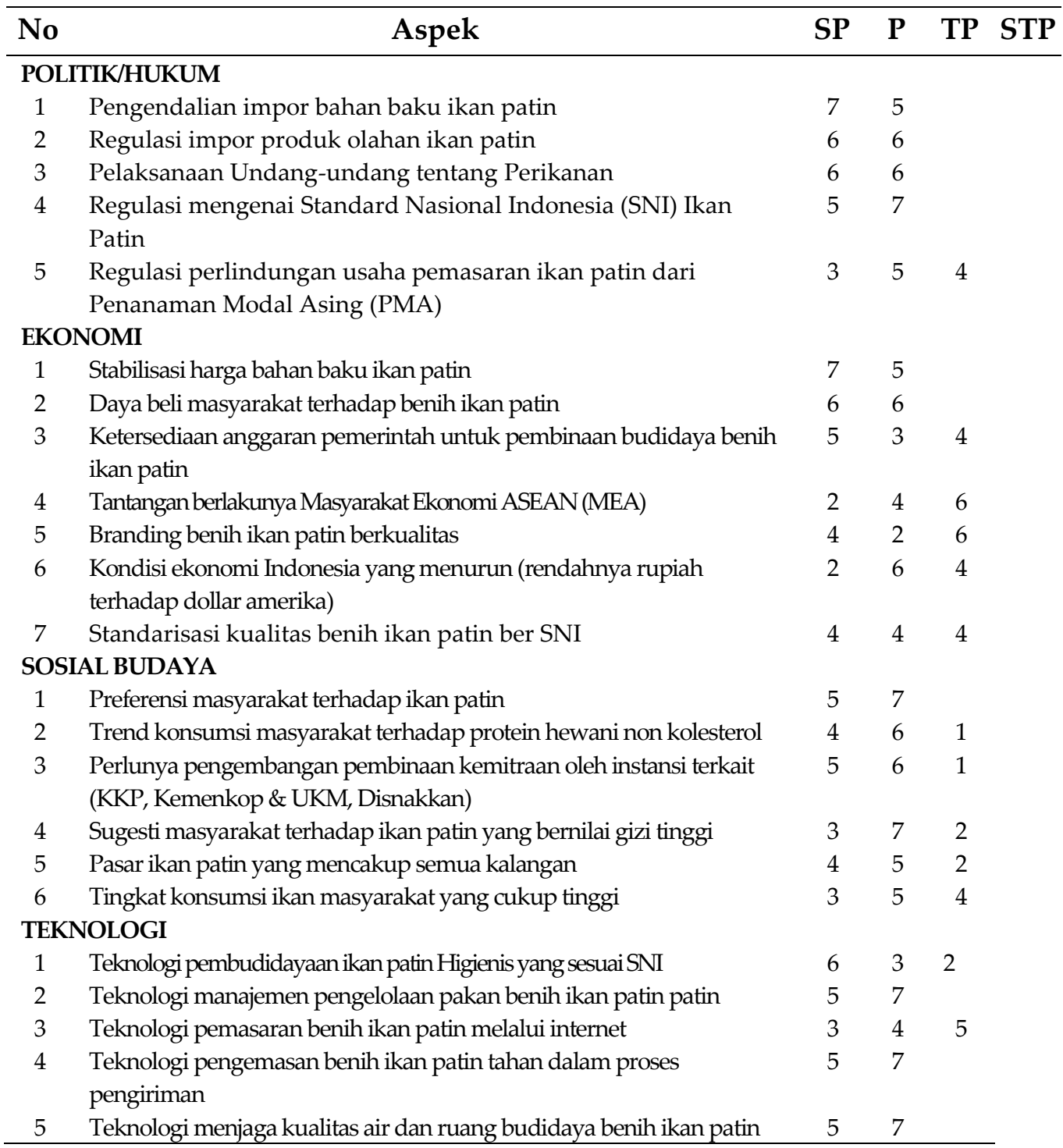




\section{Analisis Faktor Internal}

Hasil penilaian faktor-faktor internal CDKPWU dan mitra binaan dapat dilihat pada Tabel 3, kekuatan utama strategi pengembangan usaha dan pemasaran benih ikan patin di CDKPWU dan mitra binaan adalah produk bersertifikat standar nasional (ISO 901:2008 PPPC) dengan skor 0,3566, pendampingan implementasi teknologi budidaya dilaksanakan dengan baik dengan skor 0,3529 serta benih yang dihasilkan memiliki kualitas yang baik dengan skor 0,3491 .
Kelemahan utama CDKPWU dan mitra binaan adalah kurangnya modal untuk pengembangan usaha dengan skor 0,2977, kurangnya kegiatan promosi dan sosialisasi pemasaran dengan skor 0,2675, serta keterbatasan penambahan induk unggulan dengan skor 0,2646 . Total skor yang diperoleh pada matriks IFE ini berada di atas skor 2,5 yaitu 3,3799 yang menunjukkan kondisi internal CDKPWU dan mitra binaan cukup kuat dan relatif mampu menggunakan kekuatan yang dimiliki untuk mengantisipasi kelemahan yang dimiliki.

Tabel 3. Matriks IFE strategi pemasaran dan pengembangan usaha CDKPWU dan mitra

\begin{tabular}{|c|c|c|c|}
\hline Faktor Strategis Internal & Bobot & Rating & Skor \\
\hline \multicolumn{4}{|l|}{ Strengths } \\
\hline $\begin{array}{l}\text { 1. Pendampingan implementasi teknologi budidaya } \\
\text { dilaksanakan dengan baik }\end{array}$ & 0,0882 & 4 & 0,3529 \\
\hline 2. Benih yang dihasilkan memiliki kualitas yang baik & 0,0873 & 4 & 0,3491 \\
\hline 3. Produk bersertifikat standar nasional (ISO 901:2008 PPPC) & 0,0891 & 4 & 0,3566 \\
\hline 4. Memiliki pelanggan tetap & 0,0857 & 3 & 0,2571 \\
\hline 5. Sebagian besar kebutuhan bahan baku mudah diperoleh & 0,0879 & 3 & 0,2637 \\
\hline $\begin{array}{l}\text { 6. Memiliki model kemitraan (CDKPWU sebagai inti dan mitra } \\
\text { binaan sebagai plasma merupakan simbiosis mutualisme) }\end{array}$ & 0,0728 & 4 & 0,2911 \\
\hline \multicolumn{4}{|l|}{ Weaknesses } \\
\hline 1. Kurangnya modal untuk pengembangan usaha & 0,0850 & 3,5 & 0,2977 \\
\hline 2. Kurangnya kegiatan promosi dan sosialisasi pemasaran & 0,0892 & 3 & 0,2675 \\
\hline 3. Kapasitas produksi belum optimal & 0,0857 & 3 & 0,2571 \\
\hline 4. Pemasaran melalui internet belum optimal & 0,0697 & 3 & 0,2090 \\
\hline \multirow{2}{*}{$\begin{array}{l}\text { 5. Keterbatasan penambahan induk unggulan saat banjir di } \\
\text { kolam persiapan induk }\end{array}$} & 0,0882 & 3 & 0,2646 \\
\hline & 0,0712 & 3 & 0,2137 \\
\hline \multicolumn{4}{|l|}{ 6. Kurangnya Tenaga Kerja/SDM handal dan Terampil } \\
\hline Total & 1 & & 3,3799 \\
\hline
\end{tabular}

Tabel 4. Matriks EFE strategi pengembangan usaha dan pemasaran CDKPWU dan mitra

\begin{tabular}{|c|c|c|c|}
\hline Faktor Strategis Eksternal & Bobot & Rating & Skor \\
\hline \multicolumn{4}{|l|}{ Opportunity } \\
\hline $\begin{array}{l}\text { 1. Permintaan pasar tinggi terhadap benih ikan patin ukuran } 1 \\
\text { inchi }\end{array}$ & 0,9490 & 3 & 0,2848 \\
\hline $\begin{array}{l}\text { 2. Teknologi terapan perbenihan yang maju (sertifikat Cara } \\
\text { Pembenihan Ikan yang Baik (CPIB) }\end{array}$ & 0,0701 & 2 & 0,1402 \\
\hline 3. Sektor perikanan berkembang baik & 0,0912 & 2 & 0,1824 \\
\hline 4. Tingkat konsumsi ikan masyarakat yang cukup tinggi & 0,0874 & 2 & 0,1749 \\
\hline 5. Meningkatnya kemampuan daya beli benih bermutu (berSNI) & 0,0827 & 3 & 0,2480 \\
\hline 6. Peningkatan pendapatan masyarakat sekitar & 0,0801 & 2 & 0,1603 \\
\hline \multicolumn{4}{|l|}{ Threats } \\
\hline $\begin{array}{l}\text { 1. Kebijakan pemerintah pengurangan kuota keramba jaring } \\
\text { apung }\end{array}$ & 0,0868 & 2,5 & 0,2169 \\
\hline $\begin{array}{l}\text { 2. Tidak stabilnya harga bahan baku (pakan alami artemia) } \\
\text { budidaya benih ikan }\end{array}$ & 0,0953 & 3 & 0,2858 \\
\hline 3. Adanya persaingan dengan usaha sejenis & 0,0946 & 3 & 0,2839 \\
\hline 4. Kondisi cuaca kurang stabil & 0,0669 & 2,5 & 0,1674 \\
\hline $\begin{array}{l}\text { 5. Perlunya pengembangan pembinaan kemitraan oleh instansi } \\
\text { terkait }\end{array}$ & 0,0688 & 3 & 0,2065 \\
\hline 6. Kesulitan sumber pembiayaan & 0,0811 & 3 & 0,2433 \\
\hline Total & & & 2,5943 \\
\hline
\end{tabular}




\section{Analisis Faktor Eksternal}

Berdasarkan penilaian yang dilakukan oleh narasumber, maka diperoleh bobot dan rating yang selanjutnya diolah dan ditampilkan pada Tabel 4 sebagai matriks EFE CDKPWU dan Mitra binaan. Total skor yang diperoleh pada matriks EFE yaitu 2,5943. Hal ini menunjukkan dalam strategi pemasaran CDKPWU dan mitra binaan saat ini telah mampu mengatasi ancaman-ancaman yang mungkin timbul dengan memanfaatkan peluang yang ada.

\section{Matriks IE (Internal External)}

Hasil matriks IE pada Gambar 2 menunjukkan bahwa CDKPWU dan mitra binaan berada pada sel IV, yaitu strategi tumbuh dan kembangkan (grow dan build). Menurut David (2006), strategi yang cocok diterapkan pada CDKPWU dan mitra binaan adalah strategi intensif (penetrasi pasar, pengembangan pasar dan pengembangan produk) atau strategi (integrase ke belakang, ke depan dan horizontal). Hasil identifikasi dari kekuatan, kelemahan, peluang dan ancaman strategi pemasaran pada UMKM CDKPWU dan mitra binaan yang berada pada sel IV digunakan untuk merumuskan alternatif strategi pemasaran dan pengembangan usaha benih ikan patin di CDKPWU dan mitra binaan dengan matriks SWOT.

\section{Perumusan Alternatif Strategi Pengembangan Usaha}

Hasil analisis lingkungan internal dan eksternal, selanjutnya digunakan sebagai dasar formulasi alternatif strategi yang merupakan kombinasi dari strategi SO, WO, ST dan WT yang terangkum dalam matriks SWOT. Strategi Pengembangan Usaha pada CDKPWU dan mitra binaan berdasarkan matriks SWOT dapat dilihat pada Tabel 5.

\section{Prioritas Strategi Pengembangan Usaha}

Matriks QSPM digunakan dalam penelitian ini untuk menentukan daya tarik relatif dari masing-masing strategi. Prioritas Alternatif Strategi berdasarkan Matriks dapat dilihat pada Tabel 6. Hubeis dan Najib (2014) menjelaskan Matriks QSP secara objektif mengindikasikan alternatif strategi mana yang terbaik.

\section{Implikasi Manajerial}

Hasil analisis menunjukkan posisi CDKPWU dengan mitra binaan berada pada sel IV, yaitu strategi tumbuh dan kembangkan (grow dan build). Strategi yang cocok diterapkan pada CDKPWU dan mitra binaan adalah strategi intensif (penetrasi pasar, pengembangan pasar dan pengembangan produk) atau strategi integrasi (ke belakang, ke depan dan horizontal). Hasil identifikasi dari kekuatan, kelemahan, peluang dan ancaman strategi pengembangan usaha pada CDKPWU dan mitra binaan yang berada pada sel IV digunakan untuk merumuskan alternatif strategi pengembangan usaha benih ikan patin di CDKPWU dan mitra binaan dengan matriks SWOT. Selanjutnya, hasil Matriks SWOT dan QSPM menunjukkan tiga prioritas strategi yang dapat dilakukan untuk mengembangkan usaha, yaitu:

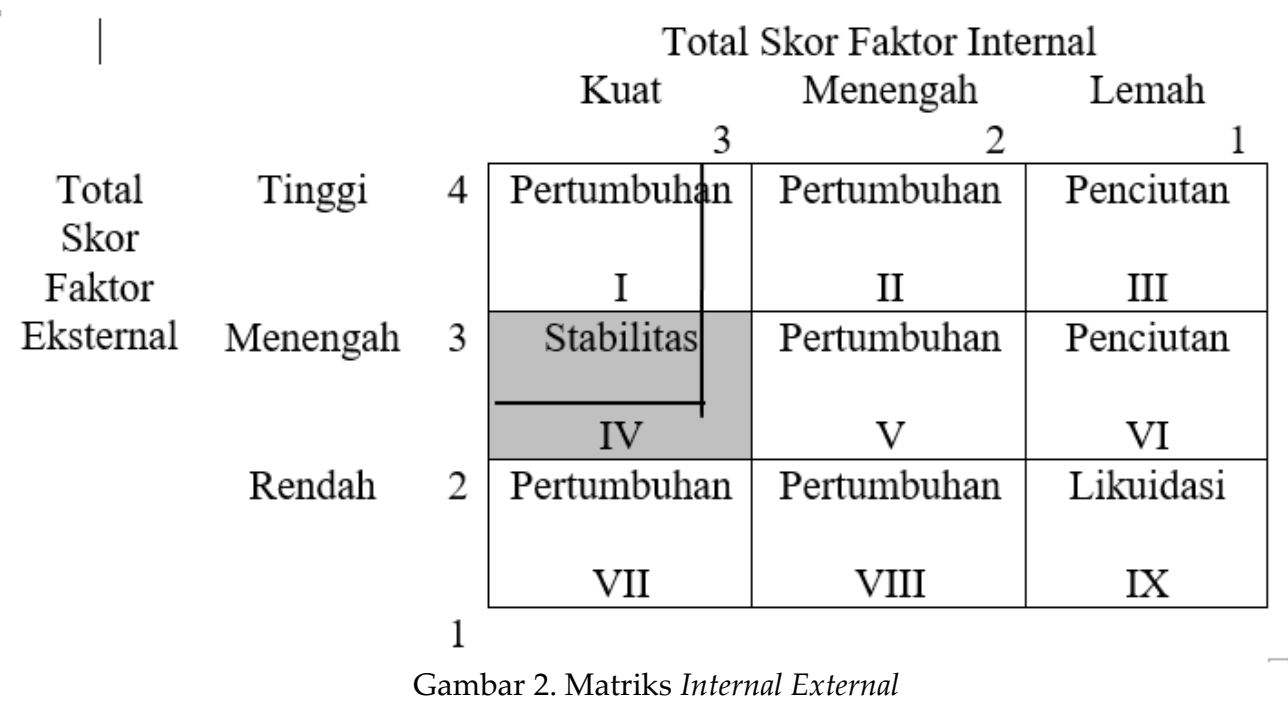


1. Memperluas jaringan kemitraan produksi untuk peningkatan produksi dan peningkatan pendapatan masyarakat (penambahan anggota mitra dan perluasan kolam produksi).
2. Mempertahankan mutu benih (ber-SNI) dan teknologi proses produksi yang baik (sertifikat CPIB).

3. Memanfaatkan kemitraan untuk menjalin hubungan baik dan melakukan audiensi (transfer informasi pasar dan akses modal) dengan instansi terkait.

Tabel 5. Matriks SWOT strategi pengembangan usaha CDKPWU dan mitra binaan

\begin{tabular}{|c|c|c|}
\hline Faktor Eksternal & $\begin{array}{l}\text { Kekuatan/Strenghts (S) } \\
\text { 1. Pendampingan implementasi } \\
\text { teknologi budidaya } \\
\text { dilaksanakan dengan baik } \\
\text { 2. Benih yang dihasilkan } \\
\text { memiliki kualitas yang baik } \\
\text { 3. Produk bersertifikat standar } \\
\text { nasional (ISO 901:2008 PPPC) } \\
\text { 4. Memiliki pelanggan tetap } \\
\text { 5. Sebagian besar kebutuhan } \\
\text { bahan baku mudah diperoleh } \\
\text { 6. Memiliki model kemitraan } \\
\text { (CDKPWU sebagai inti dan } \\
\text { mitra binaan sebagai plasma } \\
\text { merupakan simbiosis } \\
\text { mutualisme) }\end{array}$ & $\begin{array}{l}\text { Kelemahan/Weaknesses }(\mathrm{W}) \\
\text { 1. Kurangnya modal untuk } \\
\text { pengembangan usaha } \\
\text { 2. Kurangnya kegiatan promosi } \\
\text { dan sosialisasi pemasaran } \\
\text { 3. Kapasitas produksi belum } \\
\text { optimal } \\
\text { 4. Pemasaran melalui internet } \\
\text { belum optimal } \\
\text { 5. Keterbatasan penambahan } \\
\text { induk unggulan saat banjir di } \\
\text { kolam persiapan induk } \\
\text { 6. Kurangnya tenaga kerja/SDM } \\
\text { handal dan terampil }\end{array}$ \\
\hline $\begin{array}{l}\text { Peluang/Opportunities }(\mathrm{O}) \\
\text { 1. Permintaan pasar tinggi terhadap } \\
\text { benih ikan patin ukuran } 1 \text { inchi } \\
\text { 2. Teknologi terapan perbenihan } \\
\text { yang maju (sertifikat Cara } \\
\text { Pembenihan Ikan yang Baik } \\
\text { (CPIB) } \\
\text { 3. Sektor perikanan berkembang baik } \\
\text { 4. Tingkat konsumsi ikan masyarakat } \\
\text { yang cukup tinggi } \\
\text { 5. Meningkatnya kemampuan daya } \\
\text { beli benih bermutu (berSNI) } \\
\text { 6. Peningkatan pendapatan } \\
\text { masyarakat sekitar }\end{array}$ & $\begin{array}{l}\text { Strategi SO } \\
\text { 1. Mempertahankan mutu benih } \\
\text { (berSNI) dan teknologi proses } \\
\text { produksi yang baik (sertifikat CPIB) } \\
\text { (S1, S2, S3, S6, O2,O3, O5) } \\
\text { 2. Memanfaatkan teknologi budidaya } \\
\text { (sertifikat CPIB) untuk peningkatan } \\
\text { hasil produksi (S1, S2, S3,S6 O2, } \\
\text { O3,O5,O6) } \\
\text { 3. Memperluas jaringan kemitraan } \\
\text { produksi untuk peningkatan } \\
\text { produksi dan peningkatan } \\
\text { pendapatan masyarakat } \\
\text { (penambahan anggota mitra dan } \\
\text { perluasan kolam produksi) (S1, S6, } \\
\text { O1, O6) }\end{array}$ & $\begin{array}{l}\text { Strategi WO } \\
\text { 1. Meningkatkan akses permodalan } \\
\text { untuk pengembangan usaha (W1, } \\
\text { O1, O3, O4,05) } \\
\text { 2. Mengoptimalkan penggunaan } \\
\text { teknologi internet dan informasi } \\
\text { untuk peningkatkan akses pasar } \\
\text { dengan memanfaatkan media } \\
\text { online (W2, W4, O1) } \\
\text { 3. Peningkatan SDM yang handal } \\
\text { dan terampil melalui pelatihan } \\
\text { (W6, O2, O3,) }\end{array}$ \\
\hline $\begin{array}{l}\text { Ancaman/Treaths }(\mathrm{T}) \\
\text { 1. Kebijakan pengurangan kuota } \\
\text { keramba jaring apung } \\
\text { 2. Tidak stabilnya harga bahan } \\
\text { baku (artemia pakan alami) } \\
\text { budidaya benih ikan } \\
\text { 3. Adanya persaingan dengan } \\
\text { usaha sejenis } \\
\text { 4. Kondisi cuaca kurang stabil } \\
\text { 5. Perlunya pengembangan } \\
\text { pembinaan kemitraan oleh } \\
\text { instansi terkait } \\
\text { 6. Kesulitan sumber pembiayaan }\end{array}$ & $\begin{array}{l}\text { Strategi ST } \\
\text { 1.Memanfaatkan kemitraan untuk } \\
\text { menjalin hubungan baik dan } \\
\text { melakukan audiensi (transfer } \\
\text { informasi pasar dan akses modal) } \\
\text { dengan instansi terkait (S1,S6, T1, } \\
\text { T2,T3,T5, T6)) }\end{array}$ & $\begin{array}{l}\text { Strategi WT } \\
\text { 1. Menetapkan strategi harga pasar } \\
\text { untuk menghadapi persaingan } \\
(\mathrm{W} 2, \mathrm{~W} 4, \mathrm{~T} 2, \mathrm{~T} 3) \\
\text { 2. Meningkatkan kerjasama dengan } \\
\text { instansi terkait dan koperasi/UKM } \\
\text { lainnya guna mendapatkan } \\
\text { pembinaaan dan akses permodalan } \\
(\mathrm{W} 1, \mathrm{~W} 6, \mathrm{~T} 5, \mathrm{~T} 6)\end{array}$ \\
\hline
\end{tabular}


Tabel 6. Prioritas alternatif strategi berdasarkan matriks QSP

\begin{tabular}{|c|c|c|}
\hline No & Alternatif Strategi & Total Nilai \\
\hline 1 & $\begin{array}{l}\text { Memperluas jaringan } \\
\text { kemitraan produksi untuk } \\
\text { peningkatan produksi dan } \\
\text { peningkatan pendapatan } \\
\text { masyarakat (penambahan } \\
\text { anggota mitra dan perluasan } \\
\text { kolam produksi) }\end{array}$ & 7,6600 \\
\hline 2 & $\begin{array}{l}\text { Mempertahankan mutu benih } \\
\text { (berSNI) dan teknologi } \\
\text { proses produksi yang baik } \\
\text { (sertifikat CPIB) }\end{array}$ & 7,5297 \\
\hline 3 & $\begin{array}{l}\text { Memanfaatkan kemitraan } \\
\text { untuk menjalin hubungan } \\
\text { baik dan melakukan audiensi } \\
\text { (transfer informasi pasar dan } \\
\text { akses modal) dengan instansi } \\
\text { terkait }\end{array}$ & 6,9671 \\
\hline
\end{tabular}

\section{KESIMPULAN}

Berdasarkan hasil penelitian di Cabang Dinas Kelautan dan Perikanan Wilayah Utara dan mitra binaan, dapat disimpulkan bahwa:

1. Faktor internal penentu utama pengembangan usaha benih ikan patin pada CDKPWU dan mitra adalah produk hasil budidaya benih ikan yang telah memenuhi SNI (ISO 901:2008 PPPC). Faktor eksternalnya adalah permintaan pasar tinggi terhadap benih ikan patin ukuran 1 inchi sebagai peluang, dan tidak stabilnya harga bahan baku (artemia pakan alami) budidaya benih ikan sebagai ancaman.

2. Pendampingan CDKPWU kepada mitra binaan melalui pelatihan, bimbingan teknis dan pedampingan rutin dalam penanganan masalah budidaya melalui implementasi teknologi proses produksi benih ikan yang baik bersertifikat CPIB) menjadi kekuatan utama, sedangkan kurangnya modal untuk pengembangan usaha menjadi kelemahan

3. Prioritas alternatif strategi pengembangan usaha dan pemasaran benih ikan patin pada Cabang Dinas Kelautan dan Perikanan Wilayah Utara dan mitra binaan adalah memperluas jaringan kemitraan produksi untuk peningkatan produksi dan peningkatan pendapatan masyarakat melalui penambahan anggota mitra budidaya dan penambahan kolam produksi benih.

\section{DAFTAR PUSTAKA}

Barney. J.B., W.S. Hesterly. 2012. Strategic Management And Competitive Advantage Concepts and Cases. New Jersey (US): Prenctice Hall Publishing.

Budiardi, T., F. Rolin, Y. Hadiroseyani. 2014. Evaluasi usaha pendederan ikan patin di Desa Sukamandijaya. Jurnal Akuakultur Indonesia 13 (2), 152-162.

[CDKPWU] Cabang Dinas Kelautan dan Perikanan Wilayah Utara. 2018. Sasaran Produksi, Kebutuhan Benih dan Induk Ikan Patin di Jawa Barat dari CDKPWU Subang Tahun 2015-2018. Subang.

David, F.R. 2006. Manajemen Strategis: Konsep. Dono Sunardi, penerjemah. Ed ke-12. Jakarta (ID): Salemba Empat.

Gupta, A. 2013. Environmental and PEST analysis: An approach to external business environment. Merit Research Journal of Art, Social Science and Humanities, 1(2): 013-017.

Hubeis, M., M. Najib. 2014. Manajemen Strategik dalam Pengembangan Daya Saing Organisasi. Jakarta (ID): PT Elex Media Komputindo.

[KKP] Kementrian Kelautan dan Perikanan 2018. Kelautan dan perikanan dalam Angka. 2018. Jakarta. http://www.kkp.go.id [20 Desember 2018]

Mayer-Haug, K., S. Read, J. Brinckmann, N. Dew, D. Grichnik. 2013. Entrepreneurial Talent and Venture Performance: A MetaAnalytic Investigation of SMEs. Research Policy. 42(6-7):1251-1273. doi: 10.1016/j. respol.2013.03.001.

Ommani, A.R. 2011. Strengths, Weaknesses, Opportunities, Threats (SWOT) Analysis for Farming System Businesses Management: Case of Wheat Farmers of Shadervan District, Shoustar Township, Iran. African Journal of Business Management. 5(22): 9448-9454.

Pesic, M.A., V.J. Milic, J. Stankovic. 2012. Application of VRIO Framework For Analyzing Human Resources' Role in Providing Competitive Advantage. Encontros Científicos-Tourism \& Management Studies, (2): 575-586.

Rangkuti, F. 2006. Analisis SWOT: Teknik Membedah Kasus Bisnis. Jakarta (ID): Penerbit Gramedia Pustaka Utama.

Yulfiperius, I. Mokoginta, D. Jusadi. 2003. Pengaruh Kadar Vitamin E dalam Pakan Terhadap Kualitas Telur Ikan Patin (Pangasius hypophthalmus). Jurnal Iktiologi Indonesia, 3 (1): 11-18. 